\title{
Soft Skill: Its Urgency and Development at Islamic Higher Education
}

\author{
Ahmad Sabri \\ Department of Islamic Studies, Faculty of Islamic Education and Teacher Training \\ IAIN Imam Bonjol Padang, Indonesia \\ E-mail: sabri-ahmad81@gmail.com \\ DOI: http://dx.doi.org/10.15548/it.v21i3.109
}

\begin{abstract}
The success of a person in a career work is not only determined by his or her technical capability, but also the non-technical skills which is so called 'soft-skills'. It is an attitude which is exemplified among the cognitive and values in the interaction with people around. Several identified falures in the community's life indicate that many Islamic university graduates suffered from lack of ability to build harmonious relationship with the environment. Therefore, it is a high time for this institution to consistently instil some types of softskills on the parts of the students. The current study shares the urgent needs for developing students' soft-skills for Islamic colleges and universities. The paper ends up with several conclusions while promoting some commitments to be held by the faculty development including: the identification of soft-skills that have already existed in the students' minds and which need to be developed, the exploration of soft skills attributes for the next 5 years based on the inspiration or opinion of the stake holders and alumnaes, the setting of action plan for academic and non-cademic agendas, acting out the planned activities, as well as the sustainable blue-print of valid soft-skills.
\end{abstract}

Keywords: Soft skills, Islamic higher education, hard-skills, learning strategies

\section{INTRODUCTION}

It has been admitted that college education serves as part of national education subsystem which is oriented to prepare human resources who are ready to compete for better workplaces. They belong to a specific class that are able to play their roles and functions in the society. Such a supreme position does not exagerate since higher education is a final level of formal education before the graduates involve in the job markets. Yet despite the wide opportunity, undergraduate students are now suffering from their lack skills to fulfil the job markets. The case is true to the Higher Islamic undergraduates due to their unreadiness either in the lack mentality or specific skills required by the job markets. As a result, a large number of undergraduate students become jobless. In other words, they are unproductive people who rely on others' income.
Lucky enough for those who are already in the field of works especially in the Faculty of Islamic Education and Teacher Training or as employeers in the Ministry of Education and Culture. However, many of them failed to perform effective communication with their boss and other co-workers or collegues. One of the main factors of the above problem dealing with university graduates is caused by their lack soft-skills that has been supposed to provide for them during the university training or class sessions.

Soft-skills is a term in the sociology to refer to Emotional Intelligence Quotient which may be categorized into one's social life, in communication using the language, habits, hospitality, and optimism. In so far real life situation, however, college students have been overloaded with hard-skills, which in some degrees, are no bigger than soft-skills. With this in mind, hard-skills place more emphasis on IQ, promoting knowledge and science, techology 
and technical skills related to their fields or disciplines. Practitioners of Islamic Higher Education should consider this issue and pay full attention to empowering students with various soft-skills so that wider opportunity to win the competition is opened.

\section{CONCEPT OF SOFT-SKILLS}

Nowadays, the demand of workplace toward the criteria of job-seekers is getting higher. It does not only emphasize on the high academic achievement (hard-skills), but also requires such skills in values embedded in ones' personality known as soft-skills. This nontechnical skills play a great role which is comparable to academic skills.

Much of the explanation related to softskills have been published in the books and ingternet and they are basically intertwined and attributed to personality that may differentiate between one's status or career in certain jobs.

Coates (2006: ) states that interpersonality is one's skills in managing $\mathrm{him} /$ herself such as time management, stress management, change management, transformation of character, creative thinking, having positive goal reference, and fast learning technique. Intra-personality, on the other hand, is a skill to interact with the other individuals in the society or in the workplace. Within this skill, someone is able to maximize his/her performance, motivate, lead, negotiate, present, communicate, make good relationship, and talk in front of the public.

Sharma (2009: ) contends that soft-skills constitutes all aspects of generic skills which in part elements of cognitive but still related with non-academic skills. More- over, researches have identified seven soft-skills and they should be transferred or developed into the students in the college or university. They include communicative skills, thinking and problem solving skills, team-work force, life-long learning and information management, enterpreneur skill, ethics, moral and professionalism, and leadership skills.

There are several soft-skills that have had great impacts to someone's success in the world of job as reported in the following studies. First of all, Goleman (1998: ) found that one's success is not only supported by his/her intelligence particularly in using the knowledge and demonstrating the ability, but also his/her ability to manage and interact with the other people. This kind of skill is called emotional quotient. This term was first introduced by Salovery and Mayer to qualify someone's capability such as: the ability to understand the feeling of others, emphatic, and the setling of emotion to improve the quality of life (Gibbs, 1995: ). Emotional quotient reveals several skills related to accurate evaluation on one's emotion and others, to motivate, plan, and to reach the goal of life.

Secondly, the healthy life style. Marchand, et. al. (2005: ) found out that millions of dollar have been spent for nothing by the institutions and community because of minimum productivity, health service, work accident and indisciplinary of workers. The main reason for such indicators are unhealthy life style of the individual. Several topics were raised to develop include nutrition, stress management, time management, cultural diversity, and missuse of drugs. The research showed that healthy life style improved one's immune, flexibility and self concept that influence the high participation in the community.

Effective communication serves the third type of soft-skill. Cangelosi and Peterson (1998: ) found that many of the college students' failure as well as the society in the workplace were caused by their low skill in communication. One's lack of effective communication influenced the level of his/her 
self-esteem and social suppport which then influenced the success.

Beside the three elements of soft-skills described above, there are other seven dimensions that must be developed in the university level or higher education. These include communicative skills, thinking skills and problem solving skills, team work force, life-long learning and information management, enterpreneur skill, ethics, moral and profesionalism, as well as leadership skills. In addition, Wagner (2008: 14) emphasizes seven types of necessary skills for success life in the 21 th century. Such skills include: (1) Critical thinking and problem solving; (2) Collaboration through the networks and lead with the authority; (3) Flexible and adaptable; (4) Initiative and enterpreneurship; (5) Effective communication in oral and written form; (6) acessing and analyzing information; and (7) imagination and contemplation. It can be concluded then that the mastery of soft-skills are very important for the undergraduate students to sustain and successfully encounter various challenges in the works.

Soft-skills is a non-technical competence energed in one's personal characteristic. It may be reflected in someone's behavior in the interaction within the social situation, language skills, self habits, or important characters to support one's optimistic behavior. Soft-skills is used to motivate oneself so that he or she understands what he or she needs to do and be able to perform it well. Such skills are also used to overcome a small and sudden thing and be tough until they are resolved (Grugulis, : 77). Therefore, soft-skills serves as one self power to change or overcome various work problems.

Sharma summarizes the element of softskills into a table. Each soft-skills consists of several sub-skills that may be categorized into skills that are needed and good to have by an individual person.

Table 1.

Element of Soft Skills that Should be Had

\begin{tabular}{|c|c|c|c|}
\hline No & Soft Skills & $\begin{array}{c}\text { Subskills } \\
\text { Element } \\
\text { (Must Have } \\
\text { Elements) }\end{array}$ & $\begin{array}{c}\text { Subskills } \\
\text { Element } \\
\text { (Good to } \\
\text { Have } \\
\text { Elements) }\end{array}$ \\
\hline 1 & $\begin{array}{l}\text { The ability to } \\
\text { communicate }\end{array}$ & $\begin{array}{l}\text { The } \\
\text { ability to } \\
\text { present } \\
\text { idea } \\
\text { clearly, } \\
\text { effective, } \\
\text { and } \\
\text { convinci } \\
\text { ng orally } \\
\text { or in } \\
\text { writing. } \\
\text { The } \\
\text { ability to } \\
\text { practice } \\
\text { and good } \\
\text { listening } \\
\text { skill, as } \\
\text { well as to } \\
\text { respond. } \\
\text { The } \\
\text { ability to } \\
\text { present } \\
\text { somethin } \\
\text { g clearly } \\
\text { and } \\
\text { convince } \\
\text { the } \\
\text { audience }\end{array}$ & $\begin{array}{l}\text { The } \\
\text { ability to } \\
\text { use } \\
\text { technolo } \\
\text { gy } \\
\text { during } \\
\text { the } \\
\text { presentat } \\
\text { ion } \\
\text { The } \\
\text { ability to } \\
\text { discuss } \\
\text { and } \\
\text { draw } \\
\text { conclusi } \\
\text { on to } \\
\text { reach } \\
\text { consens } \\
\text { us } \\
\text { The } \\
\text { ability to } \\
\text { commun } \\
\text { icate } \\
\text { with the } \\
\text { individu } \\
\text { al who } \\
\text { has } \\
\text { different } \\
\text { cultural } \\
\text { backgro } \\
\text { und } \\
\text { The } \\
\text { ability to } \\
\text { use non- } \\
\text { oral } \\
\text { skills }\end{array}$ \\
\hline
\end{tabular}




\begin{tabular}{|c|c|c|c|c|c|c|c|}
\hline & & & $\begin{array}{l}\text { The } \\
\text { ability to } \\
\text { affect } \\
\text { one's } \\
\text { commun } \\
\text { icative } \\
\text { skills to } \\
\text { other } \\
\text { people }\end{array}$ & & & $\begin{array}{l}\text { and work } \\
\text { effectivel } \\
\text { y with } \\
\text { the other } \\
\text { people } \\
>\text { The } \\
\text { ability to } \\
\text { understan } \\
\text { d and }\end{array}$ & $\begin{array}{ll}\text { and } \\
\text { coordina } \\
\text { te it into } \\
\text { group- } \\
\text { work } \\
\Rightarrow \text { Be } \\
\text { responsi } \\
\text { ble for } \\
\text { group }\end{array}$ \\
\hline \multirow[t]{3}{*}{2} & \multirow[t]{3}{*}{$\begin{array}{l}\text { The ability to } \\
\text { think and } \\
\text { solve } \\
\text { problems }\end{array}$} & \multirow{3}{*}{\begin{tabular}{|l} 
The \\
ability to \\
identify \\
and \\
analyze \\
problems \\
in critical \\
situation \\
and to \\
make \\
justificati \\
on \\
The \\
ability to \\
enlarge \\
and \\
revise \\
thinking \\
skills like \\
giving \\
explanati \\
on, \\
analyzing \\
and \\
evaluate \\
discussio \\
n \\
The \\
ability to \\
get an \\
idea and \\
seek for \\
alternativ \\
e \\
sollution \\
\end{tabular}} & \multirow{3}{*}{$\begin{array}{l}\text { The } \\
\text { ability to } \\
\text { think } \\
\text { further } \\
\text { The } \\
\text { ability to } \\
\text { draw } \\
\text { conclusi } \\
\text { on based } \\
\text { on valid } \\
\text { evidence } \\
\text { The } \\
\text { ability to } \\
\text { accept } \\
\text { and } \\
\text { delegate } \\
\text { responsi } \\
\text { bility } \\
\text { The } \\
\text { ability to } \\
\text { understa } \\
\text { nd other } \\
\text { people } \\
\text { and } \\
\text { place } \\
\text { him to } \\
\text { various } \\
\text { work } \\
\text { atmosph } \\
\text { ere }\end{array}$} & & & $\begin{array}{l}\text { serve as } \\
\text { the role } \\
\text { of leader } \\
\text { and } \\
\text { member } \\
>\text { The } \\
\text { ability to } \\
\text { understan } \\
\text { d, } \\
\text { appraise } \\
\text { and } \\
\text { appreciat } \\
\text { e } \\
\text { behavior } \\
\text { and } \\
\text { belief of } \\
\text { others }\end{array}$ & decision \\
\hline & & & & 4 & $\begin{array}{l}\text { Life long } \\
\text { learning and } \\
\text { information } \\
\text { management }\end{array}$ & $\begin{array}{l}\text { The } \\
\text { ability to } \\
\text { manage } \\
\text { relevant } \\
\text { informati } \\
\text { on from } \\
\text { various } \\
\text { sources } \\
\text { The } \\
\text { ability to } \\
\text { accept } \\
\text { new } \\
\text { ideas }\end{array}$ & $\begin{array}{l}\text { The } \\
\text { ability to } \\
\text { develop } \\
\text { the } \\
\text { desire to } \\
\text { investiga } \\
\text { te and } \\
\text { search } \\
\text { the } \\
\text { knowled } \\
\text { ge }\end{array}$ \\
\hline & & & & 5 & $\begin{array}{l}\text { Enterpreneur } \\
\text { ship skills }\end{array}$ & $\begin{array}{l}\text { The } \\
\text { ability to } \\
\text { identify } \\
\text { job } \\
\text { opportunit }\end{array}$ & $\begin{array}{l}\text { The } \\
\text { ability to } \\
\text { propose } \\
\text { business } \\
\text { opportun }\end{array}$ \\
\hline 3 & Team-Work & $\begin{array}{l}\text { The } \\
\text { ability to } \\
\text { build } \\
\text { relations } \\
\text { hip, } \\
\text { interact }\end{array}$ & $\begin{array}{l}\text { The } \\
\text { ability to } \\
\text { contribut } \\
\text { e to a } \\
\text { certain } \\
\text { planning }\end{array}$ & & & $\mathrm{y}$ & $\begin{array}{l}\text { ity } \\
\text { The } \\
\text { ability to } \\
\text { build, } \\
\text { explore } \\
\text { and seek }\end{array}$ \\
\hline
\end{tabular}




\begin{tabular}{|c|c|c|c|}
\hline & & & $\begin{array}{l}\text { for } \\
\text { business } \\
\text { and } \\
\text { work } \\
\text { opportun } \\
\text { ity }\end{array}$ \\
\hline 6 & $\begin{array}{l}\text { Ethics, moral } \\
\text { and } \\
\text { professionalis } \\
\text { m }\end{array}$ & $\begin{array}{l}\text { The } \\
\text { ability to } \\
\text { understan } \\
\text { d } \\
\text { economic } \\
\text { crises, } \\
\text { and } \\
\text { social } \\
\text { and } \\
\text { cultural } \\
\text { aspect } \\
\text { The } \\
\text { ability to } \\
\text { analyze } \\
\text { and to } \\
\text { decide on } \\
\text { ethical } \\
\text { problem } \\
\text { solving }\end{array}$ & $\begin{array}{l}\text { The } \\
\text { ability to } \\
\text { practice } \\
\text { behavior } \\
\text { al ethics } \\
\text { and be } \\
\text { responsi } \\
\text { ble for } \\
\text { the } \\
\text { commun } \\
\text { ity }\end{array}$ \\
\hline 7 & $\begin{array}{l}\text { Leadership } \\
\text { skills }\end{array}$ & $\begin{array}{l}\text { Knowled } \\
\text { geable in } \\
\text { basic } \\
\text { leadershi } \\
\text { p theory } \\
>\text { The } \\
\text { ability to } \\
\text { lead a } \\
\text { project }\end{array}$ & $\begin{array}{l}\text { The } \\
\text { ability to } \\
\text { understa } \\
\text { nd and } \\
\text { be the } \\
\text { alternati } \\
\text { ve leader } \\
\text { as well } \\
\text { as } \\
\text { member } \\
\text { The } \\
\text { ability to } \\
\text { supervis } \\
\text { e a } \\
\text { group } \\
\text { member }\end{array}$ \\
\hline
\end{tabular}

According to Elfindri et.al (2011:67), soft-skills is a life-skill, either for oneself, group, or community, as well as toward The Creator. Individual existence in the community will emerge with all these skills including the ability to communicate, emotional skills, language skills, skills to group, having moral and ethics, mild and spiritual skills.
Furthermore, Elfindri et.al (2011:175) believe that soft-skills constitutes all characters that encourage one's hard-skills. Soft-skills direct someone to use his/her hard-skills. If someone has adequate soft-skills, his/her mastery of knowledge and skills give great prosperity and convinience as well as to his/her environment. On the other hand, being lack of this skills, he or she tends to endanger him/herself or other people.

Almost in similar way, Mulyono (2011:99) states that 'soft-skills is a complement of hard-skills. This kind of skill is part of someone's intelectual quotient and it is often the basic requirements for the promotion and special job'. Ariwibowo as cited in Sailah (2008:17) believes that soft-skills is a skills to connect with the other people. It includes values, motivation, behavior, habit, character, and attitude. These attributes are held by everyone in different quality which is affected by way of thinking, speaking, acting, and behaving. But these attributes can be changed if the person changes them through training to get used to new things.

Based on the definitions above, it can be formulated that soft-skills is basically a fostered skill on one individual. As complementary need of hard-skills, it can be developed as to keep the balance of the two skills.

\section{SOFT- SKILLS IN THE EDUCATIONAL ENTERPRISE}

Soft-skills learning is very important to be given to college students for parts of their livestock to face the workplace and industry. Even this skills is also needed by vocational students as workers are required to have soft-skills. Based on the survey of National Association of Colleges and Employee (NACE, 2002) as cited in Elfindri et.al., (2011: 156), job market requires 19 skills as seen in the table below. 
Table 2

List of 19 Skills Required in Job Market

\begin{tabular}{|c|c|c|c|}
\hline Skills & Score & $\begin{array}{l}\text { Classificati } \\
\text { on of Skills }\end{array}$ & $\begin{array}{l}\text { Rank of } \\
\text { Urgency }\end{array}$ \\
\hline $\begin{array}{l}\text { Communic } \\
\text { ation }\end{array}$ & 4,69 & Soft skill & 1 \\
\hline $\begin{array}{l}\text { Fairness/ } \\
\text { integrity }\end{array}$ & 4,59 & Soft skill & 2 \\
\hline $\begin{array}{l}\text { Cooperatio } \\
\mathrm{n}\end{array}$ & 4,54 & Soft skill & 3 \\
\hline $\begin{array}{l}\text { Interperson } \\
\text { al }\end{array}$ & 4,5 & Soft skill & 4 \\
\hline $\begin{array}{l}\text { Etos kerja } \\
\text { yang baik }\end{array}$ & 4,46 & Soft skill & 5 \\
\hline $\begin{array}{l}\text { Motivation/ } \\
\text { inisiative }\end{array}$ & 4,42 & Soft skill & 6 \\
\hline $\begin{array}{l}\text { Adaptabilit } \\
\text { y }\end{array}$ & 4,41 & Soft skill & 7 \\
\hline Analitical & 4,36 & $\begin{array}{l}\text { Kognitif } \\
\text { hard skill }\end{array}$ & 8 \\
\hline Computer & 4,21 & $\begin{array}{l}\text { Psikomotor } \\
\text { hard skill }\end{array}$ & 9 \\
\hline $\begin{array}{l}\text { Organizatio } \\
\mathrm{n}\end{array}$ & 4,05 & Soft skill & 10 \\
\hline $\begin{array}{l}\text { Detail } \\
\text { Orientation }\end{array}$ & 4 & Soft skill & 11 \\
\hline Leadership & 3,97 & Soft skill & 12 \\
\hline $\begin{array}{l}\text { Self- } \\
\text { Confidence }\end{array}$ & 3,95 & Soft skill & 13 \\
\hline $\begin{array}{l}\text { Polite/well- } \\
\text { manner }\end{array}$ & 3,82 & Soft skill & 14 \\
\hline Wise & 3,75 & Soft skill & 15 \\
\hline $\begin{array}{l}\text { Average } \\
\text { Score Index } \\
>3,00\end{array}$ & 3,68 & $\begin{array}{l}\text { Kognitif } \\
\text { hard skill }\end{array}$ & 16 \\
\hline Creative & 3,59 & Soft skill & 17 \\
\hline Humorist & 3,25 & Soft skill & 18 \\
\hline $\begin{array}{l}\text { Enterprene } \\
\text { urship } \\
\text { Skills }\end{array}$ & 3,23 & Soft skill & 19 \\
\hline
\end{tabular}

It is clear from the table that 16 out of 19 skills required in the job market are soft-skill aspects in which the seven top ranks are also occupied by soft-skills. That is why soft-skills such as commuication skills and enterpreneurship are very urgent to be provided in the process of education. In addition, the writer of self management book serial, Ariwibowo, devides the soft skills into two parts, namely intrapersonal skills and interpersonal skills. Sailah (2008:18) quotes that "intrapersonal skills is a skills to manage oneself. Intrapersonal skills should be given prior to his or her first contact with other people".

Based on the study conducted by Humbret (1996), almost all of the leaders in the world have good interpersonal skills. It is evidenced from their ability in maintaining long lasted relationship with collegues, friends, and counterparts. People who are good at their fields also have good interpersonal skills. They are able to maintain their commitment, keep feeling, honour other people, and place other people appropriately. According to Maslow as cited in Journey of Adulthood (1996), parts of characteristics of those who have actualized themselves are deep loving relationship, having the privacy but not proud, high humorist but often tells excellent lessons.

Widodo as cited in Handbook of SoftSkills in the University (2008:18) mentions that in the process of selection in the manufactory, candidates' logical thinking skills and analytical thinking are the first two requirements, then, followed by the selection of character and attitude towards the work. While in the last session, testee's technical skills and academic skills were selected. During the interview session, soft-skills like effective communication, critical thinking, apprasing others, attitudes and work motivation were demanded.

It can be concluded that the existence of soft-skills are necessary beginning from the recruitment process until they ar in the workplace. The balance of hard and soft-skills are vital. If someone only posseses hard-skills, 
he/she will be taken away by those who are rich of soft-skills. As already put forward, both hard and soft-skills must be implanted early in school. The question is that how to produce such skills so that they are integrated in teaching and learning process?

Teaching and learning process in school must be planned, otherwise all the activities will not run well. This plan which is known as scenario of education or usually called curriculum. It is a set of planning and management about goal, content, and learning materials as well as method as a guide to reach certain goal. Law of the Republic of Indonesia Number 20 which issued in 2003 about System of National Education mentioned that all curriculum in all level and types of education shall be developed under the principles of diversification in accord with the unit of education, local content, and learners.

Based on the above explanation, the current school curriculum is unit of education level curriculum. In line with Government Decree 19 Year 2002 Chapter 1, Verse 1 article 15 , this curriculum should be arranged and carried out in each of educational level based on the local content and students potential.

There are some principles in the development of this curriculum such as: 1) Centered in potential, development, needs, and concerned on students and their environment, 2) Varied and united, 3) Responsive to the development of science and technology, and arts, 4) Relevant to daily needs, 5) Thorough and continuation, 6) Life-long learning, 7) Balanced with the national and local interest. However, there are two important elements that must be considered to formulate a curriculum, such as scientific vision and market signal.

Scientifi vision on the curriculum constitutes the ideas of practitioners or groups of teacher who have future insights that are able to predict the ability of graduates in the field of agro-technology which is needed by the future work based on the development of knowledge and technology in the management they develpoed. Market signal is a sign of market requirement on certain graduates competence on management who are able to work professionaly. This market signal can be accessed from alumnaes, stakeholders and students.

The activity of formulating the curriculum is started with self assessment of the Study Program by using SWOT analysis (Strength, Weakness, Opportunities, and Threats). The implementation of this model is affected by vision and mission as well as values developed through the study program which is known as scientific vision. The results of such an analysis must be able to provide information about the capaability of the study program in the following aspects including managerial, human resources, sources of facility, financial sources, and academic environment.

The two elements above are united to formulate the profile of graduates that is the role they have to do in their life works. This role may refer to a specific profession or a particular job such as manager of a business, advocates, academic, etc., or a general form of work such as communicator, creator, leader, negosiator, which is proposed by the study program. So, this profile is formulated to label the graduates based on the vision, mission, the institutional values, inputs from the users, alumnaes, associates and stake holders. Another supporting decision in the formulation of study program is that prediction on work-spaces resulted in the direction of development in Indonesia either for job-seekers or job-creators.

Once the the profile has been formulated, then the next step is to arrange the 
components that must exist in the creation of the profile of the graduates. These components consist of core competence, supporting component, and other competences. The first or core competence is one's ability to succesfully perform his/ her competence on a specific working condition. Supporting competence is one's competence that supports the core competence, while the other competences are those that may help them improve the quality of life. It is important to note that all competences must contain somethings that may serve as foundation for personality development, increase the mastery of knowledge and skills to ensure that the graduates will work based on the behaviors and be able to improve his or her understanding of norms of social life as stated in his alternative choices of field.

The designed curriculum does not only improve hard skills, but also soft-skills. Suproto as cited in Yamin (2008: ) states the urgent need to have a curriculum that can keep the balanced of the two skills to create a high competitive graduates. It is mainly to accommodate the technical aspect and the spirit of technopreneurship. An Islamic Higher graduate should have intrapersonel and interpersonel concerns as well as extrapersonel concerns, too. It means that he or she does not only have to master the knowledge and skills, but also be able to communicate them through self work, as well as in the teamworks through his critical, logical, and analytical thinking. When he becomes an interpreneur, he may be a wise businessman and not greedy but cares his environment.

It can be concluded then that a principle in the curriculum planning should be based on the outputs of the program which may fulfil the needs and the demand of community (professional needs), industrial society (industrial needs) and community at large (societal needs). The society demands the outputs that have personal competence (soft skills) professional competence (hard skills). Personal competence contains more of attitude elements, while professional comoetence emphasizes more to the ability to use the knowledge and skills as well as wisdom on the particular field.

The second stage in the curriculum design is to identify the performance of each competence that will influence the system of evaluation that demonstrate cognitive, psychomotoric, and affective domains. The third stage is formulating ways of transfering the core of the subjects so that they can be evaluated in accordance with the desired performance. The fourth stage is formulating the study which will be turned into the course or subject. The roadmap of this subject can be made to evaluate the whole competence achievement together with its elements. This roadmap should be able to identify the relationship of the course to the other subjects in the framework of the achievement of a particular competence or sub-competence, as well as to show the relevance of the curriculum to the competences found in the work place. The matrix system of the subject versus the presented competence can be created to check whether or not the identified competences have been accomodated in various subjects. A subject may offer one or more competence, thus, a competence can also be built through one or more subjects.

By refering to the principles in the curriculum development above, it seemed that the elements of soft-skills have been put forward. As a matter of fact, the works require the workers who have appropriate soft-skills such as the potential improvement of intelligence and interest in accordance with the levels of development and ability of the 
students. The development of such a point has not yet discriminated what the higher institution wants to develop. To implement all of these points are an not easy thing since soft-skills have not been considered appropriately. If soft skills have been integrated into the curriculum, however, then the learning process will be devoted to its implementation so that softskill development become united.

Based on these principles, the development of soft-skills element for Vocational school students have rised some interest as they are stated to be relevant with life need. Unit level curriculum is intended to develop students' capacity which is relevant to the vocational skills. The implementation of such a curriculum may not be easy since there were little appreciation toward soft-skills. If it is inetgrated in the school curriculum, then more attention should be given to the teaching and learning process so that the development of students' soft-skills may serve as common goal.

A possible way to integrate the softskills into the school curriculum can be done through the following steps (Elfindri, et. al., (2011:137). First of all, state the general and specific goal of instruction. It is important to consider that teacher or lecturer must be able to formulate things to be achieved which is appropriate with the previous domain of education. Second, insert types of desired softskills into every learning sessions. When each competence is formulated, consider the methods in such a way that may develop the desired softskills. Third, Plan for the implementation of the activities either in each learning session or in several sessions. Fourth, do a try-out in a group of student. Observe the students so that we can identify changes in the students before and after the class. Supposed that a teacher wants to do a classroom action research, the changes in the students' soft-skills must be measured after giving some treatments. Fifth, review the results of try-out for revision. The process in the implementation of soft-skills is not an easy one, therefore, the teacher needs to be patient and always review the activity among the steps taken. Sixth, finalization of learning method. After some repeated treatments, write a teaching manual containing materials, teaching method, aspects of skills being developed, and ways of conducting them (Elfindri et.al, 2011: 137).

It is important to note that soft-skills is not to be given in separate subject, but they should be integratedly developed among all subjects. Therefore, teachers should be caution in every step he or she gets through the skills beginning from planning until the teaching manual is made.

Teaching and learning process of softskills should be set through the integration of some models. It follows then that the instructions should be in line with the learning of hard-skill patterns. It does not need specific or extra budgetting but still gives benefits to strenghening hard skills. Soft-skill learning is integrated in connected model approach and nested model (Forgarty, 1991:xiv ) and (Drake, 2007: 28-29). The connected model emphasizes on the interrelationships among soft-skills and hard-skills on every topics, concepts, skills, and with current work field as well the future. Nested model, however, is oriented to achieve multiple skills and target. Within this model, soft-skills learning is integrated loosely. The measured soft-skills is packed in every learning activity. The improvement of responsibility and discipline runs hand in hand with the practical subjects. This choice is based on the idea that the competence of ptactical subject is supposed to empower the students with standardized work competences. These subjects emphasize on mastery of competence which is needed in the 
world of job. It is also supposed to rise students professionalism.

\section{THE URGENCY OF SOFT-SKILL}

Various advertisements of job vacancies require the workers to work in group, are willing to work hard, have strong integrity, fair, and be responsible, etc. The adds then mention the academic requirements. The companies tend to select the workers who are good at softskills although they are weak at hard-skills. The logical reasons behind these principles are educating and training the competence are much easier than training and developing the workers' characters which are relevant to the vision and mission of the company.

Many researches convinced that individual success in work is influenced by personal character of the individual. Those researches are then direct to enquire type of personal character that support one's success in the work. Based on many theories of personality, five factors personality has been used to examine success in work. These five factors of personality represent specific characteristic of the individual which are unique and relatively stabil. They include: (1) Individual power or strength which is indicated by the character of hardwork, systematic, never give up, high motivation and immune to workloads; (2) Extraversial which is marked by such skills in maintaining relationship and effective communication, easy going, coopreative, active, tend to work in group, attractive and assertive; (3) Hospitality which is indicated by friendly attitude, mild, does not want to overact, symphatetic, warm, truthful and polite; (4) stabil emotion which is marked by calm, uneasy to lose sight and depressed, easy to accept, uneasy to get mad, and self confidence; (5) Open to experience which is indicated by having imaginative thinking skills, like to have challenges, anti-establishment, creative, crtical, and have great curiosity (Barrick, et. al, 2001: ).
Personal force and emotional stability have been the two great predictors of all the five factors above toward the success in work place (Barrick, et al, 2001: ). The other three factors indirectly serve as predictors of success depending on work criteria being held. For example, extraversial is more suitable for work that requires interpersonal relationship or negotiation, then the individual with friendly type fits in such the work of cooperative. The opened type is better suit to researcher or creative team. Current research found that the role of personality type to success is mediated by motivation. That means the effectiveness of the role decreases if it is not supported by strong motivation.

In the year of 2001, one of the popular universities in Indonesia has met with stakeholders, job feeder and other users. On that ocassion, the rectorate called for the users to provide feedbacks and use the university graduates as many as possible. The meeting with at least 10 industrial companies finally resulted in a positive respond in which Schlumberger, one of the multinasional companies, confirmed that university graduates lacked of commitment to the careers that they had lower average progress career. Out of $75 \%$ of last 20 year intake, there were only $38 \%$ who successfully achieved the manager position or above. Despite their high intelligence and good academic reputation, yet they were weak at hard working as well as dedication. Experts on managemen believe that if there are two persons with equal hardskill, the winner and the more success person in the future is the one with higher soft-skills.

\section{DEVELOPMENT OF SOFT SKILLS IN TEACHING AND LEARNING}

Soft-skill is not a name of subject matter but it is a students' non-technical skills that must be developed in every subject. All of the lecturer must be able to integrate it into the learning process so that the students are able to sharpen and develop it for their own benefits. The integrated learning of hard and soft-skills is 
very neeeded since soft-skills is not less important than hard-skills. Through appropriate learning strategies soft-skills becomes a learning process that may be implemented in the classroom.

According to Elfindri et.al (2011:177), soft skills may be taught through hard skillsbased soft-skills. There are some tips that must be done such as follows: (1) High confidence. A teacher or lecturer should start with a high confidence that he or she is able to teach both hard and soft-skills at the same time. Of course the teacher should master them both, unless he or she has to improve content knowledge while teaching it. (2) Designing Instructional Planning. A teacher may wish to teach type of soft-skills that students want to learn. For example, better communication skill. So, he should plan the activities that require the students to communicate in front of the class. (3) Use appropriate learning strategies. It will be more difficult to teach soft-skills if it merely based on theory. In oder to be understood by the students, then, soft-skills must be taught through modeling or giving examples. It requires then that teacher must be able to act like a model so that the students have examples to direct their behavior. However, it continuously challenges the teacher to improve her soft-skills, too. (4) Provide the students with Guidance. As a matter of fact, students need a guidance in developing their soft-skills. Under the teacher's guidance, students recognise the kind of soft-skills they should develop for their own benefits

In addition to the above strategies, Sailah (2008:37) contends that soft-skills may be developed through internal affections, including:

\section{Role model}

It is a model by which the teacher model something for the students. The teacher must be able to present good example of disciplines of class hours. He or she must come on time so that students will do the same.

\section{Message of the week}

Through Message of the week, the teacher gives moral messages while teaching and learning process takes place. It can be done by giving motivational words to encourage them to do something

\section{Hidden curriculum}

The lesson from hidden curriculum is always presented as additional competence in every learning session. However, the soft-skills may also be implemented through integrating them with extra-curricular activities which is done in the school yard or board.

Based on the strategies discussed above, it can be concluded that effective learning strategies enable the students to acquire the softskills through direct experience or exposure to contextual life. Another effective strategy is through modeling. By implementing appropriate strategies, soft-skills can be integrated in every learning situations so that it may produce qualified human resources which is not only good in hard-skills, but also in soft-skills.

\section{CONCLUSION}

The future of a nation is determined by its young generations especially those who have gained university education. The case is true to Muslim generations who have experienced in both West and Muslim countries. They are expected to be more aggressive and competent to access the jobs available and be more competitive than the other job seekers. There is no other way except by empowering them with various skills as well as non-technical skills which are included in both hard and soft-skills. This should be the moral responsibility of each Islamic Higher Education Institutions.

To achieve such goal, successful operational development strategy for soft-skills in Islamic Higher Education should initiate the following tenets: (1) Deep care and strong commitment to the development of students' soft-skills; (2) Identification of attributes of 
students' soft-skills soft-skills that have already been possessed and need to be developed in the future; (3) Plans for concrete academic and nonacademic agendas; (4) Conduct the activities based program assessment; (5) Creation of a sustainable blue-print of soft-skills development.

\section{REFERENCES}

Agustian, A. G. (2001). ESQ: Rahasia Sukses Membangun Kecerdasan Emosi dan Spiritual. Penerbit Arga. Jakarta.

Bafadal, I. (2003). Manajemen Peningkatan Mutu Sekolah Dasar Dari Sentralisasi Menuju Desentralisasi, Jakarta, Bumi Aksara.

Basith, A. (2004). Berani Sukses. PT. Grhadika. Jakarta.

Coates, D.E. (2006). People Skill Training. Pen.

Departemen Pendidikan dan Kebudayaan. (2003). Undang-Undang Sistem Pendidikan Nasional Nomor 20 Tahun 2003, Jakarta, Sinar Grafika.

Departemen Pendidikan Nasional. (2004) Kurikulum 2004: Kerangka Dasar, Jakarta, Depdiknas.

Elfindri, dkk. (2011). Soft-Skills Untuk Pendidik. Baduose Media.

Hamalik, O. (2008). Dasar-Dasar Pengembangan Kurikulum, Bandung, Remaja Rosdakarya.

Idi, A. (2011). Pengembangan Kurikulum, Teori dan Praktek, Jakarta, Gaya Media Pratama.

Kementerian Pendidikan dan Kebudayaan. (2012). Dokumen Kurikulum 2013.
Klaus, P. (2007). The Hard Truth about Soft Skills. Harpen Collins Publisher, New York.

Kunandar. (2013). Penilaian Autentik (Penilaian Hasil Belajar Peserta Didik Berdasarkan Kurikulum 2013), Jakarta, Rajawali Pers.

Majid, A. (2014) Pembelajaran Tematik Terpadu, Bandung, Remaja Rosdakarya.

Mulyasa. (2013). Pengembangan dan Implementasi Kurikulum 2013, Bandung, Remaja Rosdakarya.

Neff, T.J. \& Citrin, J.M. (2001). Lesson from the Top. Doubleday Business, New York.

Nurdin, S. (2002). Profesional dan Implementasi Kurikulum, Jakarta, Ciputat Press.

Peraturan Pemerintah Nomor 19 Tahun 2005 Tentang Standar Nasional Pendidikan, Jakarta, Badan Standar Nasional Pendidikan, 2006.

Pui, A. I.S, Sharma \& Mehrotra. (2009). A Comparison of Alternative for Dayli to Sub-Dayli Rainfal Disagregation, 18th World IMCS MoDSIM Congress, Cairns, Australia 13-17 Juli 2009.

Putra, I.S. \& Pratiwi A. (2005). Sukses dengan Soft Skills. Direktorat Pendidikan, ITB. Bandung.

Quilliam. S. (2003). Positive Thinking. Dorling Kindersley Limited. London.

Sailah, I.(2008). Pengembangan Soft-Skills di Perguruan Tinggi. Jakarta: Direktorat Jenderal Pendidikan Tinggi.

Samani, M. (2007). Menggagas Pendidikan Bermakna. Penerbit SIC. Surabaya.

Salinan Lampiran Peraturan Menteri Pendidikan dan Kebudayaan Nomor 67 Tahun 2013 tentang Kerangka Dasar dan Struktur 
251 | Volume 21, Number 3, November 2014, Page 239-251

Kurikulum Sekolah Dasar/Madrasah
Ibtidaiyah.

Tim Pengembang PGSD. (1997). Pembelajaran

Terpadu D-II PGSD, Jakarta, Depdiknas.

Undang-Undang RI Nomor 12 Tahun 2012

tentang Pendidikan Tinggi. 